Article

\title{
Production, Characterization, and Industrial Application of Pectinase Enzyme Isolated from Fungal Strains
}

\author{
Sudeep KC ${ }^{1,2}$, Jitendra Upadhyaya ${ }^{3}$, Dev Raj Joshi ${ }^{2}{ }^{\oplus}$, Binod Lekhak ${ }^{2}$, \\ Dhiraj Kumar Chaudhary ${ }^{4}\left(\mathbb{D}\right.$, Bhoj Raj Pant ${ }^{5}$, Tirtha Raj Bajgai ${ }^{6}$, Rajiv Dhital ${ }^{7}$, \\ Santosh Khanal ${ }^{8}$ (D), Niranjan Koirala ${ }^{9,10, *(D)}$ and Vijaya Raghavan ${ }^{3, *}$ \\ 1 Department of Public Health/Pharmacy, Central Institute of Science and Technology, Pokhara University, \\ Kathmandu 44600, Nepal; sudeep0137@gmail.com \\ 2 Central Department of Microbiology, Tribhuvan University, Kathmandu 44600, Nepal; \\ joshi_devraj@hotmail.com (D.R.J.); binod.lekhak@microbiotu.edu.np (B.L.) \\ 3 Department of Bioresource Engineering, McGill University, Macdonald Campus, 21, 111 Lakeshore Road, \\ Ste-Anne-de-Bellevue, Montreal, QC H9X 3V9, Canada; jitendra.upadhyaya@mcgill.ca \\ 4 Department of Life Science, College of Natural Sciences, Kyonggi University, Suwon 16222, Korea; \\ dhirajchaudhary2042@gmail.com \\ 5 Nepal Academy of Science and Technology, Khumaltar, Lalitpur 44600, Nepal; bhojraj.pant@nast.gov.np \\ 6 Minhas Microbrewery, Distillery and Winery, 131444 Ave NE, Calgary, AB T2E 6L6, Canada; \\ tirraj@yahoo.com \\ 7 Department of Food Science, University of Missouri, Columbia, MI 65211, USA; dhitalrajiv7@gmail.com \\ 8 Department of Microbiology, National College, NIST, Khusibu, Kathmandu 44600, Nepal; \\ santoshkhanal007@gmail.com \\ 9 Department of Natural Products Research, Dr. Koirala Research Institute for Biotechnology and Biodiversity, \\ Kathmandu 44600, Nepal \\ 10 Laboratory of Biotechnology, Faculty of Science and Technology, University of Macau, Macau SAR 999078, China \\ * Correspondence: koirala.biochem@gmail.com (N.K.); vijaya.raghavan@mcgill.ca (V.R.)
}

Received: 15 April 2020; Accepted: 3 June 2020; Published: 9 June 2020

check for updates

\begin{abstract}
Pectinases are the group of enzymes that catalyze the degradation of pectic substances. It has wide applications in food industries for the production and clarification of wines and juices. The aim of this study was to isolate, screen and characterize pectinase from fungi isolated from various soil samples and evaluate its application in juice clarification. Fungal strains were isolated and screened primarily using $1 \%$ citruspectin incorporated potato dextrose agar (PDA) and secondarily using pectinase screening agar medium (PSAM) for pectinolytic organisms. The enzyme was produced by submerged state fermentation and assayed using the dinitro salicylic acid (DNS) method. From 20 different soil samples, 55 fungal isolates were screened primarily and, among them, only 14 isolates were subjected for secondary screening. Out of 14, only four strains showed the highest pectinolytic activity. Among four strains, Aspergillus spp. Gm showed the highest enzyme production at a 48 -h incubation period, $1 \%$ substrate concentration, and $30{ }^{\circ} \mathrm{C}$ temperature. The thermal stability assessment resulted that the activity of pectinase enzyme declines by $50 \%$ within $10 \mathrm{~min}$ of heating at $60^{\circ} \mathrm{C}$. The optimum temperature, $\mathrm{pH}$, and substrate concentration for the activity of enzyme was $30^{\circ} \mathrm{C}(75.4 \mathrm{U} / \mathrm{mL}), 5.8(72.3 \mathrm{U} / \mathrm{mL})$, and $0.5 \%(112.0 \mathrm{U} / \mathrm{mL})$, respectively. Furthermore, the yield of the orange juice, the total soluble solid (TSS), and clarity (\% transmittance) was increased as the concentration of the pectinase increased, indicating its potential use in juice processing. Overall, the strain Aspergillus spp. Gm was identified as a potent strain for pectinase production in commercial scale.
\end{abstract}

Keywords: pectinase; Aspergillus spp.; DNS assay; fungal isolate; pectinolytic activity 


\section{Introduction}

Pectin is an important component of the middle lamella and primary cell wall of higher plants. Pectins are high molecular weight acidic heteropolysaccharide primarily made up of $\alpha$ (1-4) linked D-galacturonic acid residues [1]. Three major pectic polysaccharides groups are recognized, all containing D-galacturonic acid to a greater or a lesser extent. They are homogalacturonan (HG), rhamnogalacturonan I (RGI), and rhamnogalacturonan II (RGII) [2-4].

Pectinases are a group of enzymes that degrade pectic substance and are classified according to their mechanism of action. For example, methylesterases remove methoxy groups from highly or partially esterified galacturonan. Polygalacturonases catalyze the hydrolysis of the glycosidic bonds in a random fashion (endopolygalacturonase) or from the nonreducing end of homogalacturonan releasing galacturonic or digalacturunic acid residues (exopoly-glacturonases) [5,6]. Pectinolytic enzymes, or pectinases, are also classified according to their mode of action and their substrate: polygalacturonases, which are sub classified as endo-polygalacturonases (E.C. 3.2.1.15) and exo-polygalacturonases (E.C. 3.2.1.67); lyases, which are sub classified into pectatelyases (E.C. 4.2.2.9 and EC. 4.2.2.2) or pectin lyases (E.C. 4.2.2.10); and pectin methylesterases (E.C. 3.1.1.11). It is recommended to use a combination of different kinds of pectinases, along with other enzymes such as cellulases and hemicelullases, as multiple enzymes can degrade different parts of the polymer, resulting in the maximal degradation of the pectin in various raw materials such as in citrus juice processing $[7,8]$. Studies have reported that pectinase of microbial origin accounts for $25 \%$ of global food and industrial enzymes sale and their market is increasing continuously [9]. Additionally, enzymes comprise a well-established global market projected to reach USD 6.3 billion in 2021 [7]. Microorganisms including fungi are promising sources of enzymes. Fungi produces numerous extracellular enzymes that possess a special effect in the decomposition of organic matter. These include pectinolytic enzymes which are excreted to break down the middle lamella in plants so that it can insert fungal hyphae and extract nutrients from the plant $[10,11]$. In addition to fungi, pectinolytic enzymes are naturally produced by many other organisms like bacteria, insects, nematodes, and protozoans [12]. For the commercial production of pectinases, Aspergillus spp., Erwinia spp., Bacillus spp., and Penicillium spp. have been extensively used $[9,13]$.

Pectinases have crucial roles in food industries. These enzymes are useful for fruit juice extraction and wine clarification; tea, cocoa, and coffee concentration and fermentation; vegetable oil extraction; preparation of jam and jellies; and pickling $[14,15]$. Furthermore, these enzymes are used in paper and pulp industries, bleaching of paper, bio-scouring of cotton, retting and degumming of plant fibers, oil extraction, wastewater treatment, poultry feed additives, protoplast fusion technology, and bioenergy production $[10,15]$.

Enzyme breakdown of the biomolecules depends upon the type of microorganisms, fermentation condition such as $\mathrm{pH}$, incubation time or cultivation time, carbon and nitrogen source, types and concentration of substrate, temperature, agitation, and use of different enzyme preparations $[16,17]$. The application of new enzymes with desirable biochemical and physicochemical characteristics and low-cost production in commercial processes has always been regarded as essential research. Keeping all the advantages into consideration, the objectives of this study were (1) to isolate and screen pectinase-producing fungi from the soil samples, (2) to optimize different parameters for maximum enzyme production and evaluate the enzyme activity with various parameters, and (3) to evaluate its potentiality in juice clarification.

\section{Materials and Methods}

\subsection{Soil Sampling}

Soil samples were collected from various regions of Nepal, geographically located at Gulmi (GPS location: $28^{\circ} 03^{\prime} 60.00^{\prime \prime} \mathrm{N} 83^{\circ} 14^{\prime} 60.00^{\prime \prime} \mathrm{E}$ ), Manang (GPS location: $28^{\circ} 33^{\prime} 7^{\prime \prime} \mathrm{N} 84^{\circ} 14^{\prime} 27^{\prime \prime} \mathrm{E}$ ), and Kathmandu (GPS location: $27^{\circ} 42^{\prime} 6.08^{\prime \prime} \mathrm{N} 85^{\circ} 19^{\prime} 14.16^{\prime \prime} \mathrm{E}$ ). These sampling sites varied in altitude 
ranging from 1700 to $5416 \mathrm{~m}$ and were rich in spoiled fruits, agro-industrial wastes, fruit pulp, composts, decaying leaves, and organic fertilizers. Altogether, 20 soil samples were collected from the depth of $20 \mathrm{~cm}$ into sterile zip-lock bags and transported to the laboratory for analysis.

\subsection{Isolation, Screening, and Identification of Pectinolytic Fungi}

Potato dextrose agar (PDA, Himedia) incorporated with $1 \%$ citrus pectin was used for the isolation and screening of pectinolytic fungi from the soil samples. For isolation, a $5 \mathrm{gm}$ soil sample was transferred to $45 \mathrm{~mL}$ of distilled water $\left(10^{-1}\right)$ serially diluted up to $10^{-6}$. From dilutions, $0.1 \mathrm{~mL}$ was inoculated by spread plate method in the prepared agar plates and incubated at $25^{\circ} \mathrm{C}$ for $3-5$ days. Different colonies were selected and subcultured onto the two different PDA plates containing pectin for duplication and incubated at $25^{\circ} \mathrm{C}$ for $3-5$ days. Fungal colonies with distinct morphology were selected and subcultured repeatedly to obtain pure culture by point inoculation. For primary screening, $1 \%(w / v)$ cetyltrimethylammonium bromide (CTAB) was flooded on one agar plate containing selected fungal colonies and incubated at $25^{\circ} \mathrm{C}$ for $1 \mathrm{~h}$. The zone of hydrolysis around the colonies indicated the pectinolytic activity of fungi and the colonies were preserved for further study. The primary screened fungal isolates were inoculated on pectinase screening agar medium (PSAM) and incubated at $25^{\circ} \mathrm{C}$ for $42 \mathrm{~h}$. The PSAM contains (in $\left.\mathrm{g} \mathrm{L}^{-1}\right):\left(\mathrm{NH}_{4}\right)_{2} \mathrm{HPO}_{4}, 3.0 ; \mathrm{KH}_{2} \mathrm{PO}_{4}, 2.0 ; \mathrm{K}_{2} \mathrm{HPO}_{4}, 3.0 ; \mathrm{MgSO}_{4}, 0.1$, pectin, 10.0; and agar, 25.0. The $\mathrm{pH}$ of the media was adjusted to 4.5. After incubation, these plates were flooded with CTAB for secondary screening [4,12]. Furthermore, fungal strains were identified by using lactophenol cotton blue stain method to observe their morphology, hyphal characteristics, presence or absence of asexual spores, the arrangement of conidia, and the reproductive structuresunder the bright field microscope under 40X magnification $[18,19]$.

\subsection{Enzyme Production}

\subsubsection{Submerged Fermentation for Enzyme Production}

Submerged fermentation $(\mathrm{SmF})$ was carried out for the enzyme production. In a conical flask, $50 \mathrm{~mL}$ of Hankin's broth was prepared, sterilized and cooled as described previously [20]. Then, $1 \mathrm{~mL}$ pre-fermenter inoculum was inoculated. The flasks were incubated in a shaking incubator at $150 \mathrm{rpm}$ and $30^{\circ} \mathrm{C}$ for $5-7$ days [21]. The pectinase activity in the fermented broth was monitored by using the dinitro salicylic acid (DNS) assay method as described previously [22].Two milliliters of the fermented broth was pipette out into a sterile tube and centrifuged at $8000 \mathrm{rpm}$ for $20 \mathrm{~min}$. The supernatant obtained was used as the crude enzyme and used for analysis. About $1 \mathrm{~mL}$ of the crude enzyme and $1 \mathrm{~mL}$ of $3 \%$ pectin were mixed in a sterile tube and incubated at $50^{\circ} \mathrm{C}$ for $15 \mathrm{~min}$. After incubation, $1 \mathrm{~mL}$ of the DNS (Dinitrosalicylic acid) reagent was added to stop the hydrolysis reaction. The mixture was then shaken to mix the content and then placed in a boiling water bath for $30 \mathrm{~min}$ for color development. The absorbance was then read at $540 \mathrm{~nm}$ spectrophotometrically running the enzyme and substrate blanks in parallel. The blank containing $1 \mathrm{~mL}$ of $0.5 \%$ pectin, $1 \mathrm{~mL}$ of sodium acetate buffer ( $0.1 \mathrm{M}, \mathrm{pH} 4.2)$ and $2 \mathrm{~mL}$ of DNS reagent was used as a control. One unit of enzyme activity was defined as the amount of enzyme which liberated $1 \mu \mathrm{mol}$ of galacturonic acid per hour under standard assay conditions.

\subsubsection{Effect of Various Factors on Enzyme Production}

To study the effect of incubation period, submerged state fermentation was carried out and DNS assay was performed every $24 \mathrm{~h}$ until 6 days. The effect of substrate concentration on pectinase production was evaluated using Hankin's broth medium containing different concentrations of pectin $(0.5,1$ and $2 \%)$ and $1 \mathrm{~mL}$ fungal inoculum. The enzyme production was assessed by DNS method after incubating the culture flask at $30^{\circ} \mathrm{C}$ for $48 \mathrm{~h}$. To study the effect of temperature on pectinase production, Hankin's broth containing $1 \%$ pectin was prepared. Then, $1 \mathrm{~mL}$ of the inoculum was 
added and incubated separately at 25,30 , and $40{ }^{\circ} \mathrm{C}$ for $48 \mathrm{~h}$. After incubation, the enzyme assay was performed using the DNS method.

\subsubsection{Enzyme Extraction and Partial Purification}

The fermentation broth was filtered through Whatman No.1 filter paper and centrifuged $\left(10,000 \mathrm{rpm}, 30 \mathrm{~min}\right.$, at $\left.4{ }^{\circ} \mathrm{C}\right)$ for $2-3$ times to remove the spores and mycelia of the organism. The filtration process was carried out in a cold condition in ice water to prevent enzyme deactivation. The supernatant represented the soluble crude extract. The crude enzyme was then mixed with three volumes of ice-cold acetone and was allowed to stand for $15 \mathrm{~min}$. The entire content was centrifuged at $4000 \mathrm{rpm}$ at $4{ }^{\circ} \mathrm{C}$ for $20 \mathrm{~min}$. The enzyme precipitate was dissolved in a sodium acetate buffer $(0.1 \mathrm{M}$, $\mathrm{pH}$ 4.2) and was stored at $4{ }^{\circ} \mathrm{C}$ for further use [23].

\subsection{Characterization of Partially Purified Pectinase Enzyme}

\subsubsection{Thermal Stability}

To assess the thermal stability, the partially purified enzyme extract was heated at $60{ }^{\circ} \mathrm{C}$ until $1 \mathrm{~h}$ had passed. At $10 \mathrm{~min}$ intervals, $1 \mathrm{~mL}$ aliquots were withdrawn and mixed with $1 \mathrm{~mL}$ of $0.3 \%(w / v)$ pectin in test tubes and the tubes were incubated at $30{ }^{\circ} \mathrm{C}$ for $10 \mathrm{~min}$. The enzyme activity was measured as described by the DNS assay method [24,25].

\subsubsection{Effect of Temperature on Enzyme Activity}

For temperature assessment, $1 \mathrm{~mL}$ of enzyme suspended on sodium acetate buffer $(0.1 \mathrm{M}, \mathrm{pH} 4.2)$ was added to $1 \mathrm{~mL}$ of $0.3 \%(w / v)$ pectin solution in sterile tubes. The tubes were incubated from 25 to $55^{\circ} \mathrm{C}$ for $15 \mathrm{~min}$. After incubation, $2 \mathrm{~mL}$ of the DNS reagent was added and incubated in a boiling water bath for $15 \mathrm{~min}$. The enzyme activity was monitored by the DNS assay method.

\subsubsection{Effect of $\mathrm{pH}$ on Enzyme Activity}

The effect of $\mathrm{pH}$ on enzyme activity was tested using sodium acetate buffer $(0.1 \mathrm{M} ; \mathrm{pH}$ range, 3.2-5.8), sodium phosphate buffer (0.1 $\mathrm{M}$; $\mathrm{pH}$ range, 5.9-7.1) and Tris- $\mathrm{HCl}$ buffer $(0.1 \mathrm{M}$; $\mathrm{pH}$ range, 7.2-9.0). Tubes containing $0.5 \mathrm{~mL}$ respective buffers were mixed with $0.5 \mathrm{~mL}$ of the enzyme. Then, $1 \mathrm{~mL}$ of $0.3 \%(w / v)$ pectin solution was added and all the tubes were incubated at $30{ }^{\circ} \mathrm{C}$ for $10 \mathrm{~min}$. Afterward, $2 \mathrm{~mL}$ of the DNS reagent was added and incubated in boiling water for $15 \mathrm{~min}$. The enzyme activity was measured by DNS assay method.

\subsubsection{Effect of Substrate Concentration on Enzyme Activity}

Pectin substrates of different concentrations ( $0.5 \%, 1.0 \%, 1.5 \%$ and $2.0 \%)$ were prepared in different tubes to evaluate the effect of substrate concentration on enzyme activity. One $\mathrm{mL}$ of enzyme suspended in acetate buffer $(0.1 \mathrm{M}, \mathrm{pH} 4.2)$ was mixed with $1 \mathrm{~mL}$ of the respective substrate concentrations. Determination of the pectinase activity was done by the DNS assay method.

\subsection{Application of Pectinase Enzyme}

Mature ripened orange fruits (Citrus sinensis) were commercially purchased from a local grocery store and stored in food processing laboratory. Prior to juice extraction, the fruits were sorted, washed and peeled. The juice was extracted using sterile small-scale juice extractor available in the laboratory. The extracted juice was pasteurized at $85^{\circ} \mathrm{C}$ for $3 \mathrm{~min}$ to inactivate the natural fruit enzymes and cooled down to $4{ }^{\circ} \mathrm{C}$. Then, different conical flasks containing $20 \mathrm{~mL}$ of orange juice were added with varying concentrations of the enzyme $(0 \%, 0.25 \%, 0.5 \%, 0.75 \%$ and $1 \%)$. All the flasks were incubated at $30^{\circ} \mathrm{C}$ for $1 \mathrm{~h}$. After incubation, the samples were then heated at $85^{\circ} \mathrm{C}$ for $3 \mathrm{~min}$ to inactivate the enzyme. The juice treated with different enzyme concentrations was filtered using Whatman No. 1 filter paper. The volume of fruit juice obtained was measured using a $50 \mathrm{~mL}$ 
measuring cylinder. The total soluble solids (TSS) was determined using a Brix refractometer (model no. CTL-REFM-BR32, LW Scientific) and expressed as degree Brix ( ${ }^{\circ}$ Brix). For clarity, the juice was shaken and $10 \mathrm{~mL}$ of juice was centrifuged at $5000 \mathrm{rpm}$ for $10 \mathrm{~min}$. The supernatant portion of the juice was used to determine percent transmittance and absorbance at $540 \mathrm{~nm}$ by spectrophotometer (SL-150, Elico) [26].

\subsection{Statistical Analysis}

All the data were statistically analyzed using Office Excel 2019 and OriginPro 8.5 software. The statistically significant ( $p$-value $<0.05$ ) of various factors on enzyme activity was determined using one-way ANOVA.

\section{Results and Discussion}

\subsection{Isolation, Screening, and Identification of the Fungal Isolates}

A total of 55 fungal strains were isolated and screened primarily. Based on the zone of hydrolysis, only 14 strains were subjected for secondary screening. During secondary screening, 4 strains designated as Gm, Lco, C, and T showed the highest pectinolytic activity with the zone of hydrolysis of $35,32,25$, and $15 \mathrm{~mm}$ in diameter, respectively. These four strains were morphologically and culturally identified as Aspergillus spp. Gm, Penicillium spp. Lco, Fusarium spp. C, and Aspergillus spp. T. Based on primary and secondary screening, Aspergillus spp. Gm was found to be a potent strain and hence was selected for further study. The Photograph 1A shows the zone of hydrolysis observed during primary and secondary screening for enzyme production. Similarly, Figure 1B,C show the colony morphology and lactophenol cotton blue staining results of the isolate, respectively. The strains of Aspergillus spp. are promising sources of pectinase enzyme. Several previous studies have demonstrated the significance of Aspergillus spp. in the commercial production of pectinase enzyme [12,25].

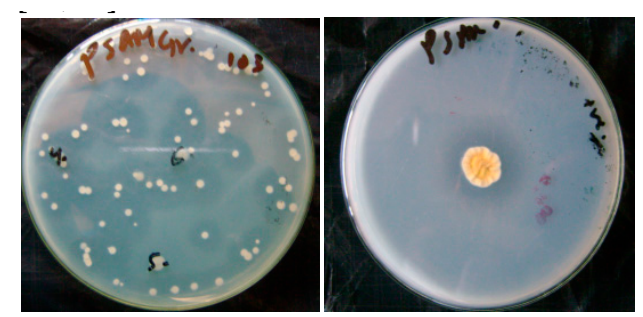

A. Primary and secondary screening

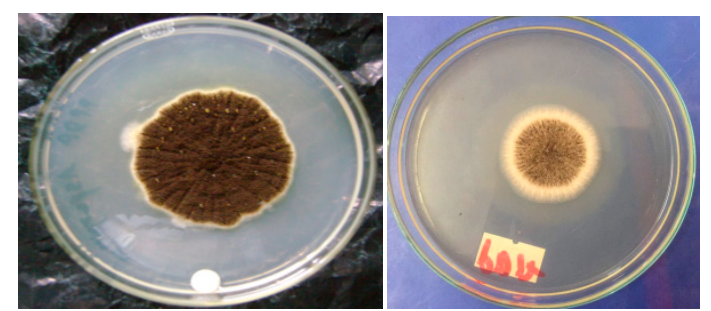

B. Colony morphology of Aspergillus spp Gm

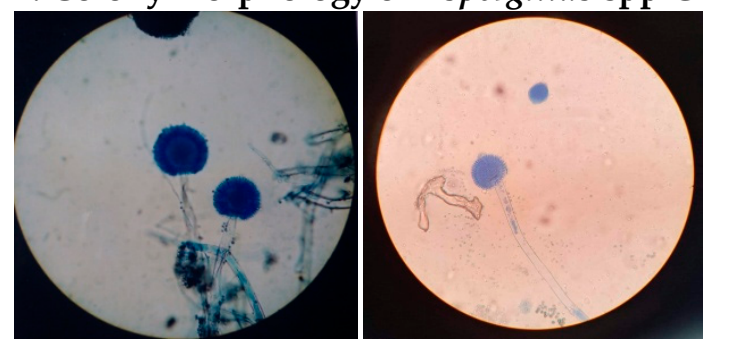

C. Microscopy of Aspergillus spp Gm

Figure 1. (A) Primary and secondary screening for Aspergillus spp. Gm. (B) Colony morphology of Aspergillus spp. Gm. (C) Lactophenol cotton staining of Aspergillus spp. Gm.

\subsection{Optimization of the Fermentation Conditions for Maximum Enzyme Production}

The strain Aspergillus spp. Gm was used to study the optimum conditions for maximum enzyme production. This strain showed the highest $(106.7 \mathrm{U} / \mathrm{mL})$ pectinase production at $48 \mathrm{~h}$ of incubation period. After $48 \mathrm{~h}$, the enzyme production was found to be decreased (Figure 2A). Various other studies have reported the highest enzyme activity of Aspergillus niger at 48-72 $\mathrm{h}$, after which the enzyme production was found to be declined $[27,28]$. The cause of decrease in enzyme production 
after certain time interval during incubation might be due to the exhaustion of essential supplements and/or accumulation of toxic metabolites in the culture medium [29]. The shorter fermentation period of $48 \mathrm{~h}$ could be advantageous for production of pectinase at industrial scale.
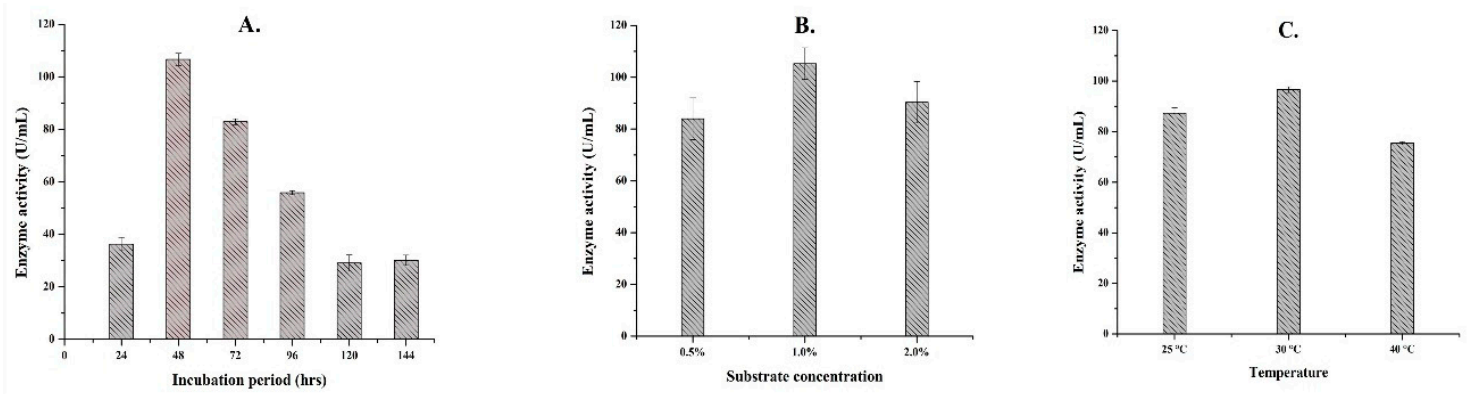

Figure 2. Optimization of the fermentation conditions for maximum enzyme production from strain Aspergillus spp. Gm. (A), effect of incubation period; (B), effect of substrate concentration; and (C), effect of temperature on enzyme production.

With $1 \%$ substrate concentration, strain Gm produces maximum pectinase of $105.2 \mathrm{U} / \mathrm{mL}$. The enzyme production was found to be decreased when the substrate was used more than $1 \%$ concentration (Figure 2B). A higher substrate concentration increases the viscosity of culture media and creates nutrient rich environment. Higher nutrients and substrate in the fermentation media inhibit microbial growth lowering enzyme production [30,31]. Previous researches have also stated that lower substrate concentration is effective for enzyme production [32,33]. The requirement of low substrate concentration might be cost effective for large scale production of pectinase enzyme.

At $30{ }^{\circ} \mathrm{C}$, activity of strain $\mathrm{Gm}$ was reported to be the highest and produces maximum $(96.7 \mathrm{U} / \mathrm{mL})$ pectinase. At a higher temperature, enzyme production declined (Figure 2C). Enzymes are usually denatured at higher temperature resulting decreased activity [34]. Previous studies have reported that the maximum yield of pectinase enzyme from the members of genus Aspergillus spp. occur at the temperature range of $30-40{ }^{\circ} \mathrm{C}[35,36]$. Among all the parameters analyzed, only temperature was found to be statistically significant $(p<0.05)$. From these optimization data, this study found that $48 \mathrm{~h}$ of incubation period, $1 \%$ substrate concentration, and $30^{\circ} \mathrm{C}$ temperature could be the optimum cultural conditions for strain Gm to produce maximum pectinase enzyme.

\subsection{Characteristics of Partially Purified Pectinase}

The optimal working ranges of partially purified pectinase enzyme produced by strain Gm were determined based on the assessment of thermal stability, temperature, $\mathrm{pH}$, and substrate concentration. The evaluation of thermal stability indicated that the activity of pectinase reduced approximately by $50 \%$ within $10 \mathrm{~min}$ of heating at $60{ }^{\circ} \mathrm{C}$. Further heat treatment until 40 min resulted complete loss in the activity of pectinase enzyme (Figure 3A). Thermal stability and activity of pectinases have crucial role in biotechnological processes and food industries. Studies have shown that pectinolytic enzymes can be stable and active at wide range of temperature $\left(30-80^{\circ} \mathrm{C}\right)[25,36,37]$. The optimum working temperature of pectinase enzyme extracted from strain $\mathrm{Gm}$ was found to be $30{ }^{\circ} \mathrm{C}$. At this temperature, pectinase enzyme showed the highest activity of $75.4 \mathrm{U} / \mathrm{mL}$ (Figure 3B). There was a significant difference in the activity of pectinase enzyme with various thermal treatment and temperature $(p<0.05)$. This feature of pectinase enzyme possesses great industrial value as it makes the enzyme less susceptible to thermal inactivation. High temperature-tolerant pectinase enzymes have been previously extracted from other various members of Aspergillus [29,36,38]. 

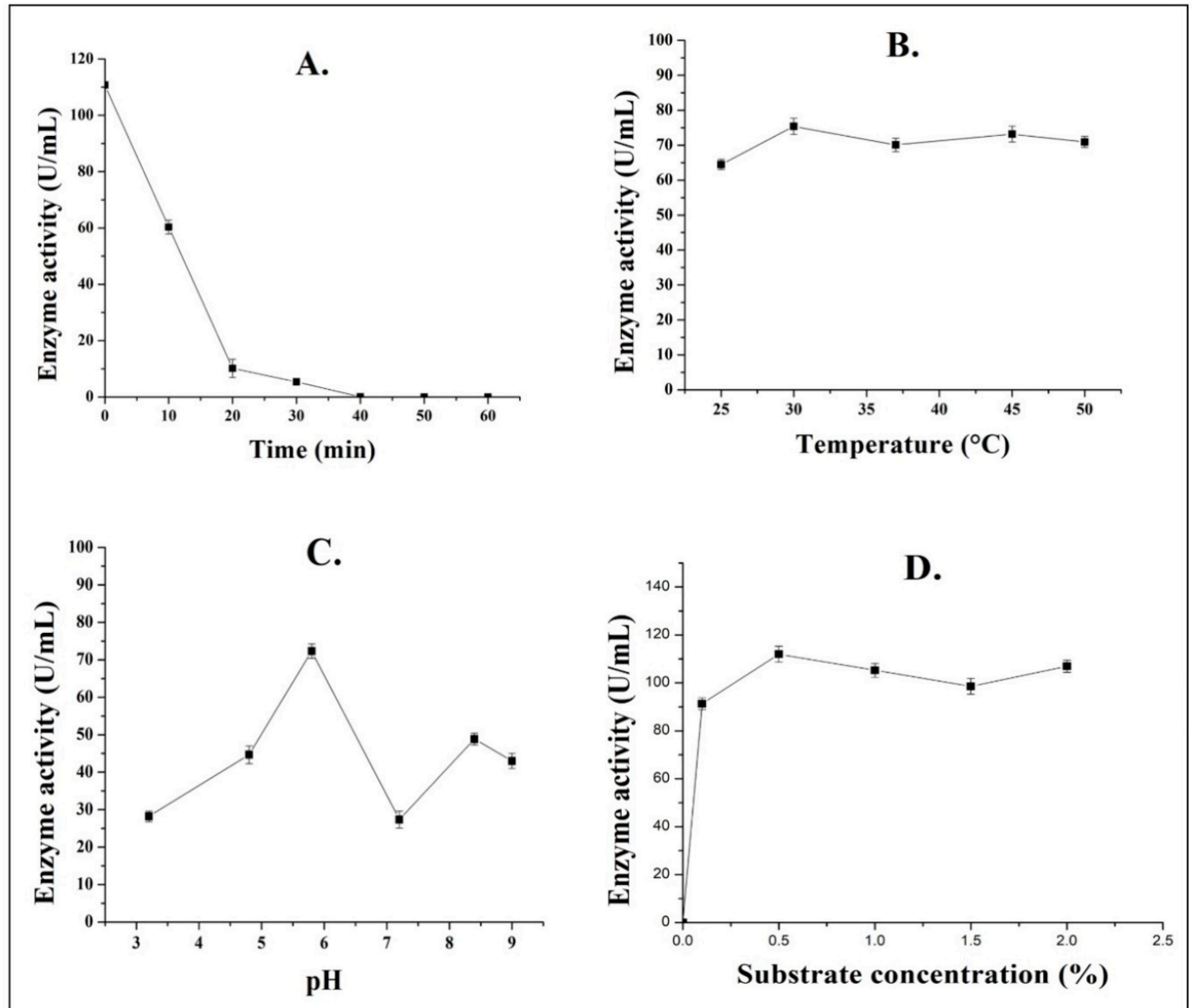

Figure 3. Effect of various factors on enzyme activity of partially purified pectinase enzyme from strain Aspergillus spp. Gm. (A), thermal stability at $60{ }^{\circ} \mathrm{C}$; (B), temperature; (C), $\mathrm{pH}$; and (D), substrate concentration.

The enzyme produced from the strain $\mathrm{Gm}$ was found to be active over a wide range of $\mathrm{pH}$ (3.2-9.0). However, the optimum enzyme activity $(72.3 \mathrm{U} / \mathrm{mL})$ was observed at $\mathrm{pH} 5.8$, indicating that the pectinase enzyme showed higher activity in theslightly acidic range (Figure 3C). The enzyme activity was significantly different with various $\mathrm{pH}(p<0.05)$. Most of the studies have reported that pectinolytic enzymes have shown to exhibit higherenzymatic activity at $\mathrm{pH}$ range of 4.0-7.0 [25,39,40]. Although the enzyme showed highest activity at $\mathrm{pH} 5.8$, a significant peak at $\mathrm{pH} 8.0$ was observed. This may be due to enzyme's activity and stability. Fungal pectinases are found to be stable from acidic to alkaline $\mathrm{pH}$ ranges (4.0-8.0) but their activity and stability may have different peaks at different $\mathrm{pH}$ ranges [41]. In a similar study, they observed the stability and optimum activity of fungal pectinases at different ranges, i.e., stability $\mathrm{pH} 4.0$, whereas the optimum activity was found at $\mathrm{pH} 10.5-11$ [42].

Acidic pectinase is useful in preparation of plant protoplast, to perform partial saccharification of sugars, to study phytopathogens invasion in plant, and in other various plant biotechnology applications [15]. However, the activity of pectinase enzyme was observed highest $(112.0 \mathrm{U} / \mathrm{mL})$ at $0.5 \%$ of substrate concentration. Numerically, the activity of pectinase varies with various substrate concentration (Figure 3D). However, statistically, there was no significant difference in the activity of enzyme with various substrate concentration $(p<0.05)$. Studies have reported that low substrate concentrations are useful to achieve higher enzyme activity [33,43]. High substrate (pectin) concentrations decrease the availability of enzymes and lower the amount of free water in the system. Free water availability is an important factor for maximum enzymatic activity [44]. Therefore, low substrate concentration $(0.5 \%)$, as observed in this study, could be useful to achieve highest activity of pectinase enzyme. 


\subsection{Application of Pectinase Enzyme in Juice Clarification}

The pectinase enzyme extracted from strain Gm was applied for juice clarification. The juice clarification experiments observed that as the concentration of enzyme increased, the yield of the juice, TSS, absorbance value, and \% transmittance also increased. At $1 \%$ enzyme concentration, the yield of the orange juice, TSS, absorbance value, and \% transmittance was found to be the highest, indicating its potential application in juice processing industries (Table 1). There are several studies which have reported that rise in enzyme concentration markedly improved the juice clarification $[45,46]$.

Table 1. Effect of different pectinase concentrations on yield, total soluble solids, and transmittance.

\begin{tabular}{|c|c|c|c|c|c|c|}
\hline \multirow{2}{*}{$\begin{array}{c}\text { Enzyme } \\
\text { Concentration (\%) }\end{array}$} & \multicolumn{2}{|c|}{ Yield } & \multicolumn{2}{|c|}{ Total Soluble Solids (TSS) } & \multirow{2}{*}{$\begin{array}{l}\text { Absorbance at } \\
540 \mathrm{~nm}\end{array}$} & \multirow[b]{2}{*}{$\%$ Transmittance } \\
\hline & $\begin{array}{c}\text { Initial } \\
\text { Volume (mL) }\end{array}$ & $\begin{array}{l}\text { Final Volume } \\
(\mathrm{mL})\end{array}$ & Initial $\left({ }^{\circ}\right.$ Brix $)$ & Final $\left({ }^{\circ}\right.$ Brix $)$ & & \\
\hline 0.25 & 20.0 & 20.2 & 5.0 & 5.5 & 0.48 & 13.0 \\
\hline 0.5 & 20.0 & 20.5 & 5.0 & 5.5 & 0.66 & 17.9 \\
\hline 0.75 & 20.0 & 21.0 & 5.0 & 6.0 & 0.70 & 19.6 \\
\hline
\end{tabular}

The major impediments to exploit the commercial potential of pectinases are the yield, stability and the cost of enzyme production. In order to obtain high and commercially viable yields of pectinase enzymes, it is essential to optimize the fermentation conditions used for fungal growth and enzyme production. Optimal parameters of the pectinases enzyme biosynthesis from microbial origin varied greatly with the variation of the strains, environmental parameters, and nutritional conditions. Furthermore, the economic feasibility of the microbial enzymes production and its application generally depends on the cost of its production processes [43].

\section{Conclusions}

In conclusion, Aspergillus spp. Gm was identified as the promising strain for the production of pectinase enzyme via submerged fermentation. The maximum pectinase production was obtained under optimal cultivation conditions at $48 \mathrm{~h}$ of incubation period, $1 \%$ substrate concentration, and $30{ }^{\circ} \mathrm{C}$ temperature. The pectinase enzyme produced from strain Aspergillus spp. Gm showed high thermal stability and reported maximum enzymatic activity at $30^{\circ} \mathrm{C}$ temperature, $\mathrm{pH} 5.8$, and $0.5 \%$ substrate concentration. In addition, the produced pectinase enzyme in this study showed proven ability in juice clarification, indicating a potential use in food industries. However, further studies must be performed to identify the strain in genetic levels and to assure its commercial application in large-scale food formulation and processing which will be the topic of interest for our research group.

Author Contributions: S.K. (Sudeep KC), D.R.J., and B.L.: Conceived and designed the work, performed the experimental work, and collection of the samples. S.K. (Santosh Khanal), T.R.B., B.R.P. and R.D.: Provide analytical tools and contribute in data analysis. D.K.C., and J.U.: data curation, manuscript preparation and manuscript editing. N.K., and V.R.: Contribute in the overall conduct, data analysis, result presentation and submission. All authors have read and agreed to the published version of the manuscript.

Funding: This research received no external funding.

Acknowledgments: We acknowledge for all the helping hands who helped to conduct this study.

Conflicts of Interest: The authors declare that they have no conflict of interest.

\section{References}

1. Kavuthodi, B.; Sebastian, D. Review on bacterial production of alkaline pectinase with special emphasis on Bacillus species. Biosci. Biotechnol. Res. Commun. 2018, 11, 18-30. [CrossRef]

2. Alkorta, I.; Garbisu, C.; Llama, M.J.; Serra, J.L. Industrial applications of pectic enzymes: A review. Process Biochem. 1998, 33, 21-28. [CrossRef] 
3. Javed, R.; Nawaz, A.; Munir, M.; Hanif, M.; Mukhtar, H.; Haq, I.U.; Abdullah, R. Extraction, purification and industrial applications of pectinase: A review. J. Biotechnol. Biores. 2018, 1, 1-6.

4. Carrasco, M.; Rozas, J.M.; Alcaíno, J.; Cifuentes, V.; Baeza, M. Pectinase secreted by psychrotolerant fungi: Identification, molecular characterization and heterologous expression of a cold-active polygalacturonase from Tetracladium sp. Microb. Cell Fact. 2019, 18, 45. [CrossRef]

5. Cornuault, V.; Posé, S.; Knox, J.P. Disentangling pectic homogalacturonan and rhamnogalacturonan-I polysaccharides: Evidence for sub-populations in fruit parenchyma systems. Food Chem. 2018, 246, 275-285. [CrossRef] [PubMed]

6. Pedrolli, D.B.; Monteiro, A.C.; Gomes, E.; Carmona, E.C. Pectin and pectinases: Production, characterization and industrial application of microbial pectinolytic enzymes. Open Biotechnol. J. 2009, 3, 9-18. [CrossRef]

7. Oumer, O.J.; Abate, D. Screening and molecular identification of pectinase producing microbes from coffee pulp. BioMed Res. Int. 2018, 2018, 2961767. [CrossRef]

8. Garg, G.; Singh, A.; Kaur, A.; Singh, R.; Kaur, K.; Mahajan, R. Microbial pectinases: An ecofriendly tool of nature for industries. Biotech 2016, 6, 1-13. [CrossRef]

9. Oumer, O.J. Pectinase: Substrate, production and their biotechnological applications. Int. J. Environ. Agric. Biotechnol. 2017, 2, 1007-1014. [CrossRef]

10. Gummadi, S.N.; Panda, T. Purification and biochemical properties of microbial pectinases-A review. Process Biochem. 2003, 38, 987-996. [CrossRef]

11. Hoondal, G.; Tiwari, R.; Tewari, R.; Dahiya, N.; Beg, Q. Microbial alkaline pectinases and their industrial applications: A review. Appl. Microbiol. Biotechnol. 2002, 59, 409-418. [PubMed]

12. Khairnar, Y.; Krishna, V.K.; Boraste, A.; Gupta, N.; Trivedi, S.; Patil, P.; Gupta, G.; Gupta, M.; Jhadav, A.; Mujapara, A.; et al. Study of pectinase production in submerged fermentation using different strains of Aspergillus Niger. Int. J. Microbiol. Res. 2009, 1, 13-17. [CrossRef]

13. Dhital, R.; Panta, O.P.; Karki, T.B. Optimization of cultural conditions for the production of pectinase from selected fungal strain. J. Food Sci. Technol. Nepal 2014, 8, 65-70. [CrossRef]

14. Barman, S.; Sit, N.; Badwaik, L.S.; Deka, S.C. Pectinase production by Aspergillus niger using banana (Musa balbisiana) peel as substrate and its effect on clarification of banana juice. J. Food Sci. Technol. 2015, 52, 3579-3589. [CrossRef] [PubMed]

15. Kubra, K.T.; Ali, S.; Walait, M.; Sundus, H. Potential applications of pectinases in food, agricultural and environmental sectors. J. Pharm. Chem. Biol. Sci. 2018, 6, 23-34.

16. Koirala, N.; Pandey, R.P.; Parajuli, P.; Jung, H.J.; Sohng, J.K. Methylation and subsequent glycosylation of 7,8-dihydroxyflavone. J. Biotech. 2014, 184, 128-137. [CrossRef] [PubMed]

17. Patidar, M.K.; Nighojkar, S.; Kumar, A.; Nighojkar, A. Pectinolytic enzymes-solid state fermentation, assay methods and applications in fruit juice industries: A review. 3 Biotech 2018, 8, 199. [CrossRef]

18. Kim, J.Y.; Lee, S.Y.; Choi, H.S. Molecular and morphological identification of fungal species isolated from rice meju. Food Sci. Biotechnol. 2013, 22, 721-728. [CrossRef]

19. Lu, Y.; Chen, C.; Chen, H.; Zhang, J.; Chen, W. Isolation and identification of endophytic fungi from Actinidia macrosperma and investigation of their bioactivities. Evid. -Based Complement. Altern. Med. 2012, 2012, 382742. [CrossRef]

20. Hankin, L.; Anagnostakis, S.L. The use of solid media for detection of enzyme production by fungi. Mycologia 1975, 67, 597-607. [CrossRef]

21. Kashyap, D.R.; Chandra, S.; Kaul, A.; Tewari, R. Production, purification and characterization of pectinase from a Bacillus sp. DT7. World J. Microbiol. Biotechnol. 2000, 16, 277-282. [CrossRef]

22. Miller, G.L. Use of dinitrosalicylic acid reagent for determination of reducing sugar. Anal. Chem. 1959, 31, 426-428. [CrossRef]

23. Rajendran, R.; Karthik, S.; Radhai, R.; Rajapriya, P.; Balakumar, C. Production and optimization of fungal pectinase from Fusarium sp. Int. J. Curr. Res. 2011, 3, 254-258.

24. Arotupin, D.J.; Akinyosoye, F.A.; Onifade, A.K. Purification and characterization of pectinmethylesterase from Aspergillus repens isolated from cultivated soil. Afr. J. Biotechnol. 2008, 7, 1991-1998. [CrossRef]

25. Maciel, M.; Herculano, P.; Porto, T.; Teixeira, M.; Moreira, K.; De Souza-Motta, C. Production and partial characterization of pectinases from forage palm by Aspergillus niger URM4645. Afr. J. Biotechnol. 2011, 10, 2469-2475. 
26. Rai, P.; Majumdar, G.C.; DasGupta, S.; De, S. Optimizing pectinase usage in pretreatment of mosambi juice for clarification by response surface methodology. J. Food Eng. 2004, 64, 397-403. [CrossRef]

27. Abdullah, R.; Farooq, I.; Kaleem, A.; Iqtedar, M.; Iftikhar, T. Pectinase production from Aspergillus niger IBT-7 using solid state fermentation. Bangladesh J. Bot. 2018, 47, 473-478. [CrossRef]

28. Rashmi, R.; Murthy, K.; Sneha, G.; Shabana, S.; Syama, A.; Radhika, V. Partial purification and biochemical characterization of extracellular pectinase from Aspergillus niger isolated from groundnut seeds. J. Appl. Biosci. 2008, 9, 378-384.

29. Phutela, U.; Dhuna, V.; Sandhu, S.; Chadha, B.S. Pectinase and polygalacturonase production by a thermophilic Aspergillus fumigatus isolated from decomposting orange peels. Braz. J. Microbiol. 2005, 36, 63-69. [CrossRef]

30. Biz, A.; Farias, F.C.; Motter, F.A.; De Paula, D.H.; Richard, P.; Krieger, N.; Mitchell, D.A. Pectinase activity determination: An early deceleration in the release of reducing sugars throws a spanner in the works. PLOS ONE 2014, 9, e109529. [CrossRef]

31. Patil, N.P.; Chaudhari, B.L. Production and purification of pectinase by soil isolate Penicillium spp and search for better agro-residue for its SSF. Recent Res. Sci. Technol. 2010, 2, 36-42.

32. Palaniyappan, M.; Vijayagopal, V.; Viswanathan, R.; Viruthagiri, T. Screening of natural substrates and optimization of operating variables on the production of pectinase by submerged fermentation using Aspergillus niger MTCC 281. Afr. J. Biotechnol. 2009, 8, 682-686.

33. Akhter, N.; Morshed, M.A.; Uddin, A.; Begum, F.; Sultan, T.; Azad, A.K. Production of pectinase by Aspergillus niger cultured in solid state media. Int. J. Biosci. 2011, 1, 33-42.

34. Al-Najada, A.R.; Al-Hindi, R.R.; Mohamed, S.A. Characterization of polygalacturonases from fruit spoilage Fusarium oxysporum and Aspergillus tubingensis. Afr. J. Biotechnol. 2012, 11, 8527-8536. [CrossRef]

35. Singh, S.; Mandal, S.K. Optimization of processing parameters for production of pectinolytic enzymes from fermented pineapple residue of mixed Aspergillus species. Jordan J. Biol. Sci. 2012, 5, 307-314.

36. Khatri, B.P.; Bhattarai, T.; Shrestha, S.; Maharjan, J. Alkaline thermostable pectinase enzyme from Aspergillus niger strain MCAS2 isolated from Manaslu Conservation Area, Gorkha, Nepal. Springerplus 2015, 4, 488. [CrossRef]

37. Deshmukh, N.; Talkal, R.; Jha, K.; Singh, P.G.; Prajapati, D.C. Production, purification, characterization and comparison of polygalacturonase from various strains of Aspergillus. Int. J. Sci. Technol. Res. 2012, 1, 85-91.

38. Dogan, N.; Tari, C. Characterization of three-phase partitioned exo-polygalacturonase from Aspergillus sojae with unique properties. Biochem. Eng. J. 2008, 39, 43-50. [CrossRef]

39. Martins, E.S.; Silva, D.; Da Silva, R.; Gomes, E. Solid state production of thermostable pectinases from thermophilic Thermoascus aurantiacus. Process Biochem. 2002, 37, 949-954. [CrossRef]

40. Mohamed, S.A.; Al-Malki, A.L.; Kumosani, T.A. Characterization of a polygalacturonase from Trichoderma harzianum grown on citrus peel with application for apple Juice. Aust. J. Basic Appl. Sci. 2009, 3, 2770-2777.

41. Jayani, R.S.; Saxena, S.; Gupta, R. Microbial pectinolytic enzymes: A review. Process Biochem. 2005, 40, $2931-2944$. [CrossRef]

42. Ferreira, V.; da Silva, R.; Silva, D.; Gomes, E. Production of pectate lyase by Penicillium viridicatum RFC3 in solid-state and submerged fermentation. Int. J. Microbiol. 2010, 1-8. [CrossRef]

43. Sandri, I.; Silveira, M. Production and application of pectinases from Aspergillus niger obtained in solid state cultivation. Beverages 2018, 4, 48. [CrossRef]

44. Demir, H.; Tari, C. Valorization of wheat bran for the production of polygalacturonase in SSF of Aspergillus sojae. Ind. Crops Prod. 2014, 54, 302-309. [CrossRef]

45. Kareem, S.; Adebowale, A. Clarification of orange juice by crude fungal pectinase from citrus peel. Niger. Food J. 2007, 25, 130-137. [CrossRef]

46. Joshi, V.; Parmar, M.; Rana, N. Purification and characterization of pectinase produced from apple pomace and evaluation of its efficacy in fruit juice extraction and clarification. Indian J. Nat. Prod. Resour. 2011, 2, 189-197.

(C) 2020 by the authors. Licensee MDPI, Basel, Switzerland. This article is an open access article distributed under the terms and conditions of the Creative Commons Attribution (CC BY) license (http://creativecommons.org/licenses/by/4.0/). 